\title{
HOMOLOGY AMONG EXTRA-CRYPTIC DNA BANDS AND THE TYPICAL PLASMIDS IN BRAZILIAN YERSINIA PESTIS STRAINS
}

\author{
Nilma Cintra Leal'; Marise Sobreira; Tereza Cristina Arcanjo Leal; Alzira Maria Paiva de Almeida \\ Departamento de Microbiologia, Centro de Pesquisas Aggeu Magalhães, Fundação Oswaldo Cruz, Recife, PE, Brasil
}

Submitted: July 27, 1999; Returned to authors for corrections: October 21, 1999; March 22, 2000

\begin{abstract}
Yersinia pestis, the etiologic agent of plague, harbors three well-characterized plasmids: pFra $(90-110 \mathrm{~kb})$, pYV $(70 \mathrm{~kb})$ and pPst $(9.5 \mathrm{~kb})$. Furthermore, some extra-cryptic DNA bands have been observed in a number of wild strains from several foci of the world. Additional bands have also been reported in Brazilian strains. Looking for any relationship among these cryptic DNA bands and the three-prototypical plasmids, we analyzed twelve strains displaying different plasmid content. The DNA bands were hybridized by southern blot with probes directed at the genes $c a f 1, l c r V$ and pla located respectively on the plasmids $\mathrm{pFra}, \mathrm{pYV}$ and pPst. The probes were constructed by PCR amplification and labeled with digoxigenin. The Pla probe hybridized with its target (pPst) and with bands of about $35 \mathrm{~kb}$ suggesting some homology among them. The Caf1 probe hybridized with the target (pFra) as well as with higher bands. The LcrV also hybridized with the target (pYV) and both with the bands higher than $\mathrm{pFra}$ and the bands between $\mathrm{pFra}$ and $\mathrm{pYV}$. These results suggest that the large-cryptic bands could represent some rearrangement, open circular or linearized forms of the pFra and pYV plasmids.
\end{abstract}

Key words: Y. pestis, plasmids, probes, virulence genes

\section{INTRODUCTION}

In Brazil, there are several independent Yersinia pestis foci in rural areas, mainly in the Northeast region (21). During the period of 1966 to 1997, we have isolated 882 strains of Y. pestis from different hosts and distinct geographic foci $(1,2)$. A preliminary evaluation of the plasmid content of 26 of these strains freshly isolated during a plague outbreak (13) has revealed a homogeneous pattern composed of the three wellcharacterized $Y$. pestis plasmids: pFra (90-110 kb), pYV (70 $\mathrm{kb})$ and pPst $(9.5 \mathrm{~kb})$, plus an extra-cryptic DNA band of about $23 \mathrm{~kb}$ (13). Another work conducted on more than 250 Y. pestis strains that were stored in our bacterial culture collection for several years, confirmed that most of the strains displayed the typical plasmid profile composed of the three classical plasmids (14). However, a number of the tested strains missed at least one of these plasmids, whereas a few strains carried extra-cryptic DNA bands (14). Based on the molecular weight, they could be grouped into three classes: one composed of bands greater than the $\mathrm{pFra}$ band $(>110 \mathrm{~kb})$, another group with band sizes ranging between those corresponding to pFra and pYV $(<110 \mathrm{~kb},>70$ $\mathrm{kb}$ ), and one group with bands smaller than the $\mathrm{pYV}$ but larger than the pPst bands $(<70 \mathrm{~kb},>9.5 \mathrm{~kb})(14)$.

In this work, using probes directed at the typical $Y$. pestis plasmids, we show a homology among them and the crypticextra DNA bands found in strains of $Y$. pestis from our collection.

\section{MATERIALS AND METHODS}

The $Y$. pestis strains studied were obtained from the bacterial collection of the "Centro de Pesquisas Aggeu Magalhães" (1, $2,13,14)$. Since isolation, they have been stored in stabs of Blood Agar Base (BAB, Difco), at $+4^{\circ} \mathrm{C}$. Subculturing some of these isolates, for different purposes, at different periods, originated some spontaneous variants. Twelve isolates and four variants, displaying different plasmid content, were selected for

\footnotetext{
* Corresponding author. Mailing address: Centro de Pesquisas Aggeu Magalhães/FIOCRUZ. CP. 7472, CEP 50670-420, Cidade Universitária, Recife, PE, Brazil. FAX: (+5581)453-2449. E-mail: nilma@cpqam.fiocruz.br
} 
this study. Table 1 shows the origin of these strains. One strain of Y. pseudotuberculosis, (YP 2952, from the Institut Pasteur, Paris collection) one of $Y$. enterocolitica (Ye 37, from IOC/ FIOCRUZ collection) and the Girard \& Robic vaccine-strain $Y$. pestis EV76 were employed as controls. Before plasmid examination, the strains were cultivated at $28^{\circ} \mathrm{C}$ in Brain Heart Infusion Broth (BHI, Difco) during 24 up to $72 \mathrm{~h}$, plated on $\mathrm{BAB}$, to ensure purity, and grown for $24 \mathrm{~h}$ in $\mathrm{BHI}$ for plasmid extraction.

In order to know if passages "in vivo" altered the plasmid content of $Y$. pestis strains, five cultures displaying different plasmid content (Table 1), have been submitted to the natural

Table 1: Origin of the Yersinia pestis strains used

\begin{tabular}{cccc}
\hline $\begin{array}{c}\text { Identification of } \\
\text { the strains }\end{array}$ & Source & Foci & $\begin{array}{c}\text { Year of } \\
\text { obtention }\end{array}$ \\
\hline P.EXU 208 & Man & Chapada do Araripe & 1968 \\
P. EXU 248 & Man & Triunfo & 1968 \\
P. EXU 324 & Man & Triunfo & 1969 \\
P. EXU 281 & Man & Chapada do Araripe & 1968 \\
P. EXU 554 & Man & Ibiapaba & 1971 \\
P. EXU 674 & Man & Chapada do Araripe & 1974 \\
P. EXU 767 & Man & Chapada do Araripe & 1975 \\
P. EXU 778 & Man & Chapada do Araripe & 1975 \\
P. EXU 807 & Man & Ibiapaba & 1978 \\
EV76 & Man & Madagascar & 1929 \\
P. EXU 216 & Rodent & Chapada do Araripe & 1968 \\
YP 216/80 & Derived from P.EXU 216 & 1980 \\
YP 216/89 & Derived from P.EXU 216 & 1989 \\
P. EXU 228 & Rodent & Chapada Araripe & 1968 \\
YP 228/89* & Derived from P.EXU 228 & 1989 \\
YP 228/93* & Derived from P.EXU 228 & 1993 \\
P. PB 881* & Man & Planalto da Borborema & 1986 \\
P. PB 543* & Man & Ibiapaba & 1971 \\
P. EXU 547* & Man & Ibiapaba & 1971 \\
\hline
\end{tabular}

*= strains used in passage "in vivo" cycle of infection (rodent/flea/rodent). With this purpose, five pools of fleas (Xenopsylla cheopis) were infected by feeding on rodents (Calomys callosus) inoculated with the strains. Infection was transmitted to healthy $C$. callomys through infected fleas bites. Dead C. callomys were autopsied, and their spleens were cultured for $Y$. pestis isolation and analysis of the plasmid content of the cultures recuperated. Rodents and fleas used in this study, obtained from the animal facilities of the CPqAM, were handled as recommended by Bahmanyar and Cavanaugh (4).

The phenotypic plasmid markers: calcium-dependent growth at $37^{\circ} \mathrm{C}$ encoded by $\mathrm{pYV}$, synthesis of coagulase and the bacteriocin pesticin encoded by pPst, and synthesis of the F1 antigen encoded by pFra (17) were studied as described previously (4).

Plasmid extraction was performed by a small scale alkaline lysis technique based on the procedure described by Birnboim and Doly (6), followed by electrophoresis in $0.6 \%$ agarose gels, in Tris-Borate buffer (TBE), under constant voltage of $100 \mathrm{~V}$, staining with ethidium bromide, and photographed under ultraviolet light (UV). The gels were then treated with $0.2 \mathrm{~N}$ $\mathrm{HCl}$ at room temperature for 15 minutes, under gentle agitation for depurination, washed in distilled water and denatured with $1.5 \mathrm{M} \mathrm{NaCl}, 0.5 \mathrm{M} \mathrm{NaOH}$, for 30 minutes, under gentle agitation. The DNA bands were then transferred from the gels to a nylon membrane by slow diffusion, overnight, in alkaline buffer $(0.25$ $\mathrm{M} \mathrm{NaOH}, 1.5 \mathrm{M} \mathrm{NaCl}$ ) as described (15). After transfer, the membranes were washed for $2 \mathrm{~min}$ in $0.3 \mathrm{M} \mathrm{NaCl}, 0.03 \mathrm{M}$ Trissodic citrate, $\mathrm{pH} 7.0$ ( 2 x SSC), air dried, and exposed to UV for $10 \mathrm{~min}$ to fix the DNA on the membrane.

The probes were constructed by PCR amplification with primers directed at published sequences of the plasmidial genes cafl, encoding the structural sub-unit of the F1 antigen (10), pla encoding coagulase and the plasminogen activator (19) lcrV encoding the $\mathrm{V}$ antigen (16), and the chromosomal irp2 gene (11). The primer sequences used are described in Table 2.

The reaction mixture, in a total volume of $25 \mu \mathrm{l}$, contained: $50 \mathrm{mM} \mathrm{KCl}, 10 \mathrm{mM}$ Tris- $\mathrm{HCl}$ (pH 8.0), $1.5 \mathrm{mM} \mathrm{MgCl}_{2}, 0.001$ $\%$ gelatin (wt/vol), $200 \mathrm{mM}$ of each dATP, dCTP, dGTP, and

Table 2: Description of the primers used.

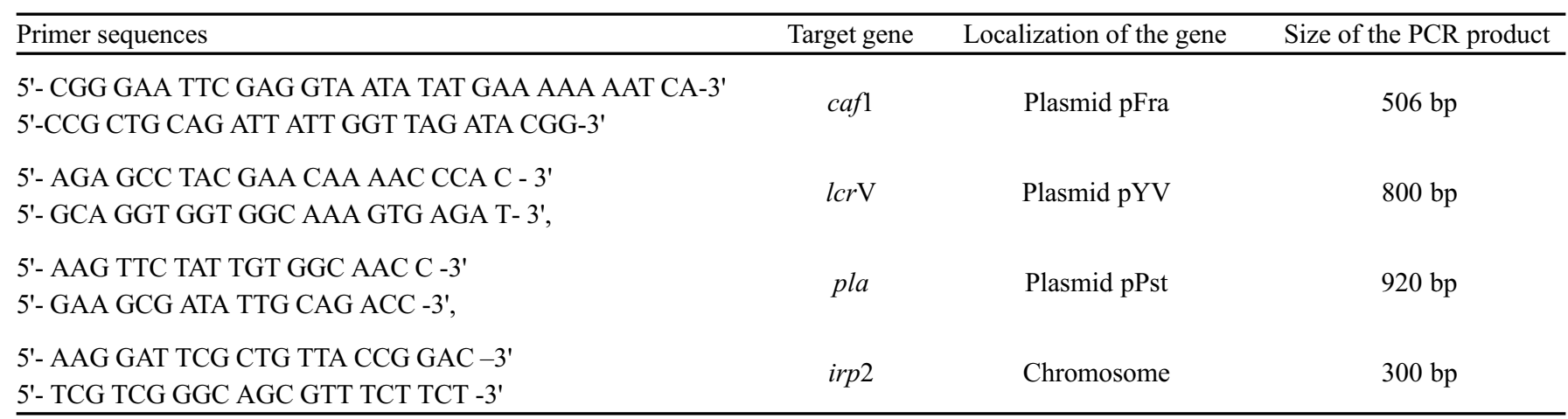


dTTP (Pharmacia), 20 pmol of each primer, $20 \mathrm{ng}$ of DNA, and $1 \mathrm{U}$ of Taq DNA polymerase (CENBIOT, RS, BR).

Amplifications were performed in a DNA thermal cycler (Perkin-Elmer) programmed for 25 cycles composed of 1 minute at $94^{\circ} \mathrm{C}, 2$ minutes at $50^{\circ} \mathrm{C}, 3$ minutes at $72^{\circ} \mathrm{C}$ and a final step of 7 minutes at $72^{\circ} \mathrm{C}$. After amplification, $3 \mu \mathrm{l}$ of each product was submitted to electrophoresis in $1 \%$ agarose gels as described, stained with ethidium bromide and photographed under UV. Then, DNA was precipitated by ethanol $\left(-70^{\circ} \mathrm{C}\right)$ and $500 \mathrm{ng}$ of each probe was labeled using Dig-DNA Labeling and Detection Kit, as specified by the manufacturer (Boehringer Mannheim).

Prehybridization, hybridization, washes and detection were performed in a hybridization oven following the protocol provided with the kit.

\section{RESULTS AND DISCUSSION}

With the intent of disclosing any relationship among extracryptic DNA bands and any of the classical Y. pestis plasmids, 12 cultures with different plasmid content were analyzed by Southern blotting (20) with probes directed at the pFra, pYV and pPst plasmids. Figs. 1 and 2 show the plasmid content of the $Y$. pestis cultures as analyzed in agarose gels, and Figs. 3 and 4 show the DNA bands recognized by the probes.

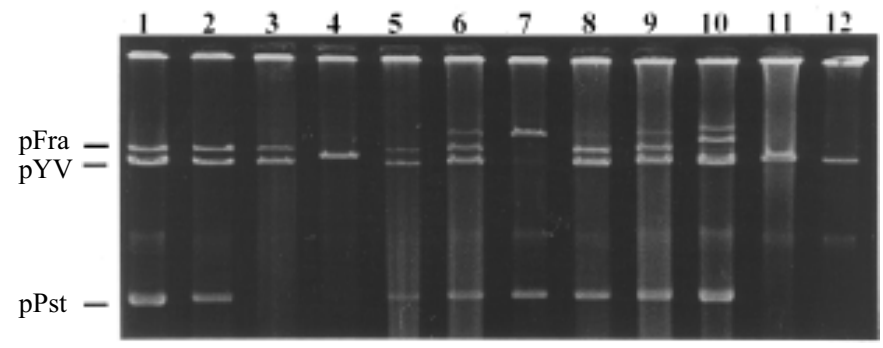

Figure 1. Plasmid content of representative Brazilian strains of $Y$. pestis, in 0,6\% agarose gel. Lane 2: P.EXU 208, lane 3: P.EXU 248, lane 4: P.EXU 324, lane 5: P.EXU 281, lane 6: P.EXU 554, lane 7: P.EXU 674, lane 8: P.EXU 767, lane 9: P.EXU 778, lane 10: P.EXU 807, and controls, lane 1: Y. pestis EV76, lane 11: YP2952, lane 12: Ye37.

The Pla probe recognized its target (pPst) in all the strains harboring pPst analyzed (Figs. 3, 4) and the bands sized between pPst and pYV plasmids, present on the variants (Fig. 4) suggesting some homology among these bands and pPst. Furthermore, all the strains carrying these bands expressed the pPst encoded properties coagulase and pesticin. Accordingly with these results, Chu et al. (7) showed that an additional-small plasmid of about $19 \mathrm{~kb}$ is likely a dimer of pPst.

The Cafl probe hybridized only with its target ( $\mathrm{pFra}$ ) or with larger bands, suggesting that they are related. Surprisingly the LcrV probe recognized its target (pYV) or bands larger than

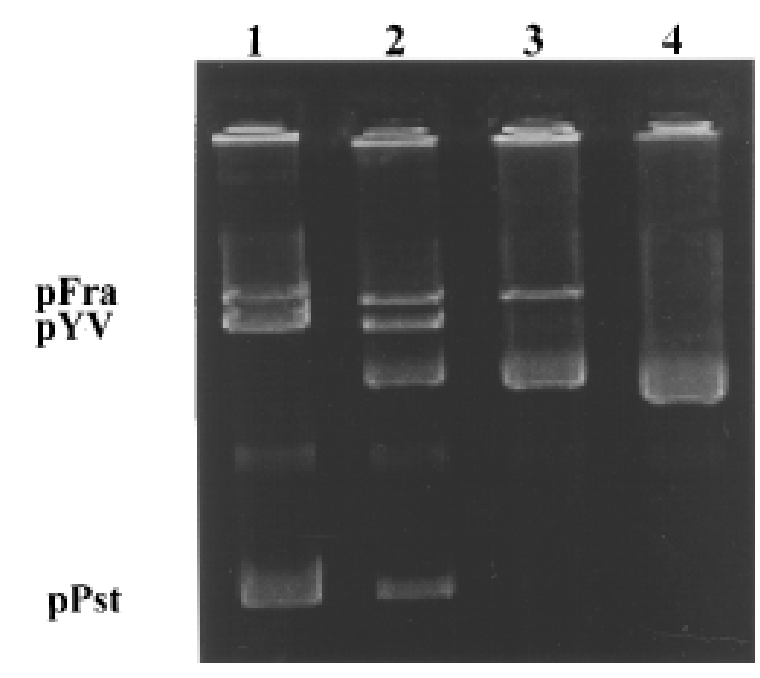

Figure 2. Plasmid content of variants derived from $Y$. pestis isolates, in $0,6 \%$ agarose gel. Lane 2: Yp 216/80, lane 3: Yp 216/89, lane 4: Yp 228/89, and control, lane 1: Y. pestis EV76.

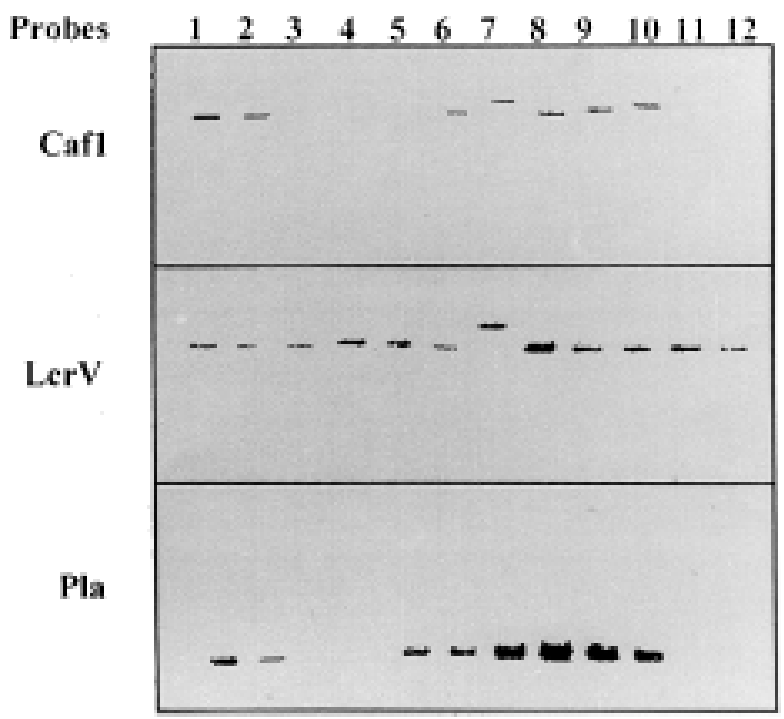

Figure 3. Southern blot hybridization of the probes Caf1, LcrV and Pla with DNA from Y. pestis cultures. Lane 1: Y. pestis EV76, lane 2: P.EXU 208, lane 3: P.EXU 248, lane 4: P.EXU 324, lane 5: P.EXU 281, lane 6: P.EXU 554, lane 7: P.EXU 674, lane 8: P.EXU 767, lane 9: P.EXU 778, lane 10: P.EXU 807, and controls, lane 11: YP2952, lane 12: Ye37. For record, the membrane was photographed immediately after the development and later digitized.

pFra or sized between $\mathrm{pFra}$ and $\mathrm{pYV}$. These results could suggest that these large bands can represent some rearrangement, open circular or linearized forms of the pFra and pYV plasmids.

Moreover, the strains had also been probed with a probe directed at the chromosomal irp2 gene. This gene is located on 


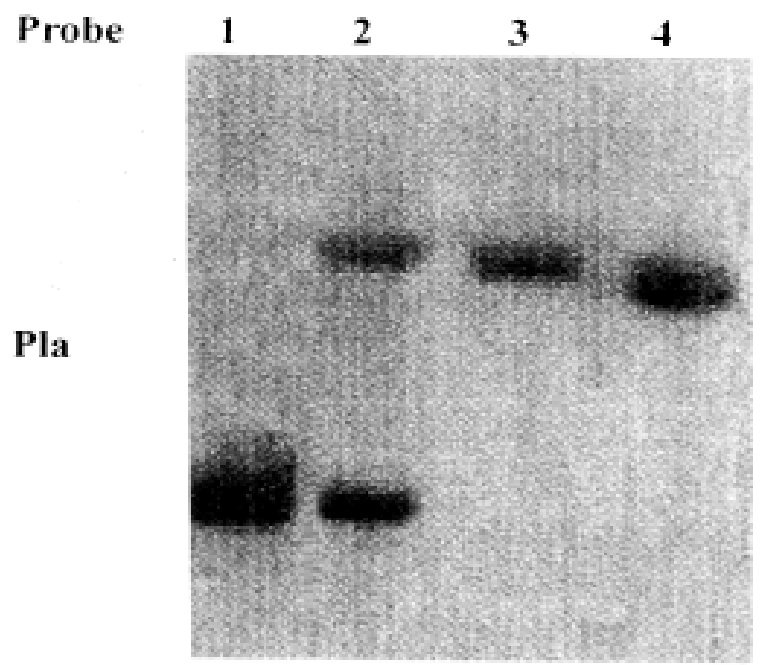

Figure 4. Southern blot hybridization of the probe Pla with DNA from $Y$. pestis cultures. Lane 1: Y. pestis EV76, lane 2: YP 216/80, lane 3: YP 216/89, lane 4: YP 228/89. For record, the membrane was digitized immediately after the development.

a chromosomal DNA fragment that deletes spontaneously at high frequency in $Y$. pestis (3). Therefore we speculated that the extra-cryptic DNA bands found in some of the Brazilian Y. pestis strains could be the irp 2 fragment. However, the Irp2 probe did not recognize any of the extra bands (data not shown). On one hand this result shows that the extra bands are not chromosomal fragments carrying the irp 2 gene and on the other hand, it proves that the probes are specific for their targets.

Protsenko et al. (18) correlated the appearance of additional plasmids and increase in plasmid molecular mass with handling Y. pestis strains in the laboratory. We also observed spontaneous modification of the plasmid profile of some strains, after subculturing. We wondered if the plasmid content of $Y$. pestis strains change through passages "in vivo". Our studies conducted with the five cultures, listed in Table 1, showed no change in their plasmid content after the "in vivo" passages. Fig,. 5 shows the plasmid content of these cultures. All of them displayed a plasmid content identical to those in the cultures inoculated. Contrary to what happens "in vitro", the environment pressure over the bacteria "in vivo" caused no change in their plasmid content, nor selection of typical clones among the atypical cultures inoculated (to be published elsewhere).

The presence of extra-cryptic plasmid bands of varied molecular mass have been reported in wild strains of $Y$. pestis and a correlation with the geographic characteristics of the foci have been put forward $(5,8)$. Recently, a large extra plasmid band found in strains isolated in Madagascar was associated with antibiotic resistance $(9,12)$. Extra-cryptic DNA bands have also been found in strains from our collection. However, we could not establish any relevant epidemiological feature

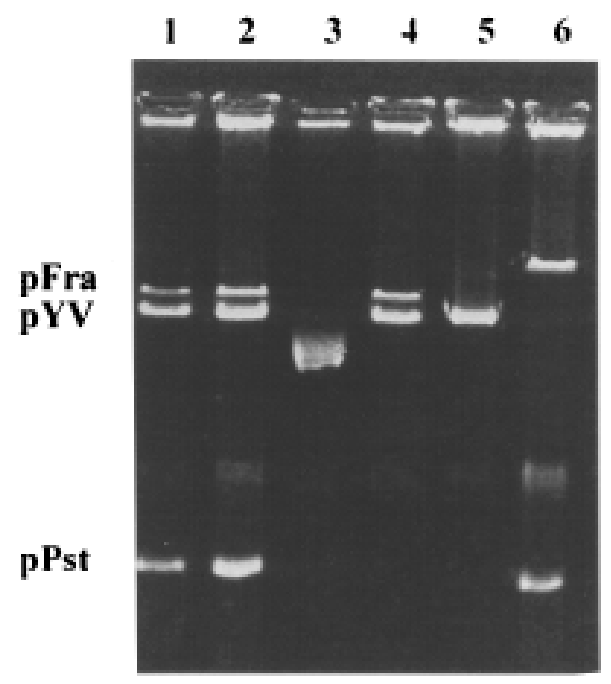

Figure 5. Plasmid content, in $0,6 \%$ agarose gel, of the $Y$. pestis cultures passed through the rodent/flea/rodent cycle. Lane 1: Yp EV76 (control), lane 2: P.PB 881, lane 3: YP 228/89, lane 4: YP 228/93, lane 5: P. EXU 547, lane 6: P.EXU 543

associated with geographical or epizootiological characteristics of the strains analyzed neither with antibiotic resistance.

Therefore, we don't believe that the Brazilian Y. pestis strains displaying atypical plasmid profiles could represent true wild type spontaneous variants. It is rather probable that these variants displaying extra-cryptic plasmid bands have been selected during prolonged storage (up to 25 years) or handling at the laboratory.

\section{ACKNOWLEDGMENTS}

We acknowledge the skilful technical assistance of Mrs Silvana Santos, Mrs Yara Nakasawa, Mrs Gisele Camposana, and Mr. Ulisses Montarroyos. Marise Sobreira Bezerra da Silva and Tereza Cristina Arcanjo Leal have Scholarships from the Brazilian Research Council (CNPq) for Ph.D. Thesis.

\section{RESUMO}

\section{Homologia entre bandas extras de DNA críptico e os plasmídios típicos em cepas brasileiras de Yersinia pestis}

Yersinia pestis, o agente causador da peste, possui três plasmídios bem caracterizados: pFra (90-110 kb), pYV (70 kb) e pPst $(9.5 \mathrm{~kb}$ ). Adicionalmente, algumas bandas extras de DNA críptico têm sido observadas em numerosas cepas selvagens em vários focos do mundo. Bandas extras também foram observadas em cepas brasileiras. Para verificar se existe alguma homologia entre as bandas extras de DNA críptico e os três plasmídios típicos, foram analisadas 12 culturas de $Y$. pestis através de hibridização com sondas dirigidas aos genes cafl, lcrV e pla 
localizados respectivamente nos plasmídios pFra, pYV e pPst. As sondas foram construídas através de amplificação por PCR e marcadas com digoxigenina. A sonda Pla reconheceu seu alvo (pPst) e bandas de cerca de $35 \mathrm{~kb}$ sugerindo que estas últimas podem se tratar de um multímero do pPst. A sonda Caf1 reconheceu seu alvo ( $\mathrm{pFra}$ ) assim como bandas mais altas. A sonda LcrV, além de reconhecer seu alvo (pYV), também hibridizou com bandas maiores que $\mathrm{pFra}$ e bandas de tamanho entre as de $\mathrm{pFra}$ e $\mathrm{pYV}$. Estes resultados sugerem que as bandas grandes poderiam ser resultantes de algum rearranjo, formas abertas circulares ou linearizadas dos plasmídios pFra e pYV.

Palavras-chave: $Y$. pestis, plasmídios, sondas, genes de virulência

\section{REFERENCES}

1. Almeida, A.M.P.; Brasil, D.P.; Carvalho, F.G.; Almeida, C.R. Isolamento de Yersinia pestis nos focos pestosos do nordeste do Brasil no período de 1966 a 1982. Rev. Inst. Med. Trop. (São Paulo). 27: 207-218, 1985.

2. Almeida, A.M.P.; Brasil, D.P.; Leal, N.C.; Melo, M.E.B.; Rego, R.V.B.; Almeida, C.R. Estudos bacteriológicos e sorológicos de um surto de peste no Estado da Paraíba, Brasil. Mem. Inst. Oswaldo Cruz. RJ. 84:249-256, 1989.

3. Almeida, A.M.P.; Guiyoule, A.; Guilvout, I.; Iteman, I.; Baranton, G; Carniel, E. Chromosomal irp2 gene in Yersinia: distribution, expression, deletion and impact on virulence. Microb. Pathogen. 14: 9-21, 1993.

4. Bahmanyar, M.; Cavanaugh, D.C. Plague Manual. Geneva, WHO, 1976.

5. Balakhonov, S.V.; Tsendzhav, S.; Erdenebat, A. New plasmidovars of Yersinia pestis strains isolated in Mongolia. Mol. Gen. Mikrobiol. Virusol. 0: 27-29, 1991.

6. Birnboim, H.C.; Doly, J. A rapid alkaline procedure for screening recombinant plasmid DNA. Nucl. Ac. Res. 6: 1513-1523, 1979.

7. Chu, M.C.; Dong, X.Q.; Zhou, X.; Garon, C.F. A criptic 19-kilobase plasmid associated with U. S. isolates of Yersinia pestis: a dimer of the 9.5-kilobase plasmid. Am. J. Trop. Hyg. 59: 679-686, 1998.
8. Filippov, A.A.; Solodovnikov, N.S.; Kookleva, L.M.; Protsenko, O.A. Plasmid content in Yersinia pestis strains of different origin. FEMS. Microbiol. Lett. 76: 45-48, 1990.

9. Gallimand, M.; Guiyoule, A.; Gerbaud, G.; Rosoamanana, B.; Chanteau, S.; Carniel, E.; Courvalin.; P. Multidrug resistance in Yersinia pestis mediated by a transferable plasmid. N. Engl. J. Med. 10: 677-680, 1997.

10. Galyov, E.E.; Smirnov, O. Yu.; Karlishev, A.V.; Volkovoy, K.I.; Denesyuk, A.I.; Nazimov, I.V.; Rubtsov, K.S.; Abramov, V.M.; Dalvadyanz, S.M.; Zav'yalov, V.P. Nucleotide sequence of the Yersinia pestis gene encoding F1 antigen and the primary structure of the protein. Putative T and B cell epitopes. FEBS Lett. 277: 230-232, 1990.

11. Guilvout, I.; Mercereau-Puijalon, O.; Bonnefoy, S.; Pusgsley A.; Carniel E. High-Molecular-Weight Protein 2 of Yersinia enterocolitica is homologous to AngR of Vibrio anguillarum and belongs to a family of proteins involved in nonribosomal peptide synthesis. J. Bacteriol. 175: 5488-5504, 1993.

12. Guiyoule, A.; Rasoamanana, B.; Buchrieser, C.; Michel, P.; Chanteau, S.; Carniel, E. Recent emergence of new variants of Yersinia pestis in Madagascar. J. Clin. Microbiol. 35: 2826-2833, 1997.

13. Leal, N.C.; Almeida, A.M.P.; Ferreira, L.C.S. Plasmid composition and virulence-associated factors of Yersinia pestis isolates from a plague outbreak at the Paraiba State, Brasil. Rev. Inst. Med. Trop. (São Paulo) 31: 295-300, 1989.

14. Leal, N.C.; Farias, R.C.L.; Silva, M.S.B.; Leal, T.C.A.; Almeida, A.M.P.; Ferreira, L.C.S. Plasmid profiles of Yersinia pestis strains isolated in northeast Brazil. Rev. Microbiol. (São Paulo) 28: 40-45, 1997.

15. Maniatis, T.; Fritsch, E.F.; Sambrook J. Molecular cloning: a laboratory manual. Cold Spring Harbor Laboratory, Cold Spring Harbor, N.Y. 1982.

16. Motin, V. L.; Pokrovskaya, M. S.; Telepenev, M. V.; Kutyrev, V. V.; Vidyaeva, N. A.; Filippov, A. A.; Smirnov, G. B. The difference in the $l c r \mathrm{~V}$ sequences between $Y$. pestis and $Y$. pseudotuberculosis and its application for characterization of Y. pseudotuberculosis strains. Microb. Path. 12: 165-175, 1992.

17. Perry, R.D.; Fetherston, J.D. Yersinia pestis-etiologic agent of plague. Clin. Microbiol. Rev. 10: 35-66, 1997.

18. Protsenko, O.A.; Filipov, A.A.; Kutyrev, V.V. Plasmid heterogeneity in populations of Yersinia pestis strains. Microb. Pathog. 11: 123-128, 1991.

19. Sodeinde, O. A.; Goguen, J. D. Genetic analysis of the 9.5 kilobase virulence plasmid of Yersinia pestis. Infect. Immun. 56: 2743-2748, 1988.

20. Southern, E.M. Detection of specific sequences among DNA fragments separated by gel electrophoresis. J. Mol. Biol. 98: 503-517, 1975.

21. Vieira, J.B; Almeida, A.M.P.; Almeida, C.R. Epidemiologia e Controle da Peste no Brasil. Rev. Soc. Bras. Med. Trop. 27: Supl. III: 51-58, 1994. 